\title{
MAIN FACTORS OF PHYSICAL DEVELOPMENT AND SPORTS FITNESS OF 15-16-YEAR-OLD BASKETBALL PLAYERS
}

\author{
Yavor Asparuhov, Mariana Borukova \\ National Sports Academy "Vassil Levski”, Sofia, Bulgaria
}

\begin{abstract}
It is often needed in basketball practice to evaluate the stage of the young basketball players " preparation. In this way the necessary information is re-

OPEN ACCESS

Submitted: 28 June 2021 Accepted: 08 July 202

ORCID iD

Yavor Asparuhov https://orcid.org/0000-0001-9551-0764 Mariana Borukova https://orcid.org/0000-0003-4403-9065

Cite this article as: Asparuhov, Y., Borukova, M. (2021) Main factors of physical developmen and sports fitness of 15-16-year-old basketball players Journal of Applied Sports Sciences, Vol.1 pp. $80-92$ DOI: $10.37393 / J A S S .2021 .01 .7$

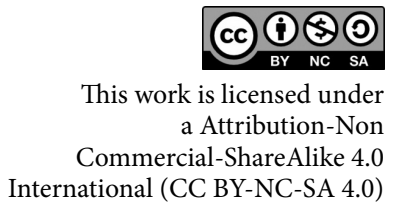

\section{INTRODUCTION}

Modern basketball is incomparable with the game from the first periods of its development. The increasing dynamics places new, higher and specific requirements on the participants in it (Tsarov, Djordjevic, 1997). For years, one of the characteristic features of training and coaching was their dependence on the composition of the team (Zhelyazkov, 1978, Tsarov, 2001, Borukova, 2018). A characteristic feature of basketball is the emphasized role of movements in the content of the game (running, jumping, throwing, passing and catching the ball, resistance, etc.). Motor actions are aimed at overcoming various difficulties and obstacles that hinder the achievement of the goal of the game. In addition, natural movements and individual skills and abilities are developed and improved in games.

To increase the efficiency of the training process, it is especially important to take into account the relationship between the physical and technical training of the basketball player.

Technical training is a process aimed at mastering sports technique, according to the tasks of the sport (Zhelyazkov, Dasheva, 2017). Within the multi-year training process, the technical preparation goes through two stages (Matveev, 1977). These are stages of basic technical training, during which the ini- 
tial training is carried out, a rich background of sports-technical skills and habits is created, serving as a basis for technical improvement, and a stage of in-depth technical improvement and mastering of sports-technical mastery (Zhelyazkov, Dasheva, 2017). During these periods, the work for the development of speed and strength abilities should not be interrupted, but when applying different means, it is necessary to apply an individual approach to the competitors.

The development of speed and strength abilities requires persistent, repeated repetition of concentrated physical exercises. Power of will is also needed to focus attention, to mobilize speed abilities at the right moment, or to maintain speed until the end of the exercise (Yahontov, 2006).

To the greatest extent, the contribution of each of the studied indicators to the sporting achievement of an individual or a set depends on 3-4 main factors.

The disclosure of the factor structure of the physical development and the specific workability of growing up basketball players has high informative value for the optimization of the educational and training process (Tzarova, Borukova, 2012).

\section{METHODS}

The aim of the study is the optimization of the education-training process for coming up basketball players by revealing the factor structure and identifying the basic factors of the sports preparedness during the age range of 15-16 years old players.

The study was conducted during the period between September 2018 and June 2019.

\section{Participants}

The research was done among 65 junior male basketball players listed in various clubs in Bulgaria at the age of $15 \pm 0.7$.The partici- pants in the study had been training organized basketball for $6 \pm 2$ years. The training sessions during the last two years had been once or two a day, six days per week. All 65 participants in the study had taken part in the National Basketball Championship for the respective age group and some of them were members of the national team project for the respective age. All clubs in the country are working according to the Common educational methodology, introduced by the Bulgarian Basketball Federation in 2018.

\section{Procedure}

The sport-pedagogical tests were applied by one and the same researcher and the coach of the respective team under terrain conditions within the frames of one regular training session (120 min). The anonymity of the children was guaranteed by listing them under a different number, (which was known by the team coach only) with the purpose to use the results for the optimization of the school-training process after processing the data. Everybody participated in the study voluntarily and received no money or financial compensation for their contribution. Nobody from the participants refused to take part in the study except those with injuries or indisposition. Short instructions, video and demonstration of the test battery were presented prior to testing. After we measured the anthropometric parameters, each team had 10-15 minutes to warm up. The tests of all were performed according to the sequence presented in Table 1. The study was performed in standard conditions - a basketball hall with the necessary equipment; chronometer, measuring apparatuses; cones, basketball balls and a medicine ball of $3 \mathrm{~kg}$. The participants performed each test twice. Their better achievements were taken in view when analyzing the results. Sports pedagogical testing was conducted with the participants for the 
needs of the study, probated and standardized test battery was used, covering 20 indicators bearing information about the basic indications of the physical development, physical preparedness and technical skills in basketball.
The indicators were divided into three groups: for physical development - from the 1st to the 4th indicator; for physical preparedness - from the 5 th to the 11th one and for technical skills - from the 12th to the 20th indicator.

Table 1. Description of the used tests in the research

\begin{tabular}{|c|c|c|c|c|}
\hline № & Indicators / Parameters & $\begin{array}{c}\text { Measuring } \\
\text { units }\end{array}$ & $\begin{array}{c}\text { Measurement } \\
\text { accuracy }\end{array}$ & $\begin{array}{l}\text { Direction } \\
\text { of growth }\end{array}$ \\
\hline 1. & Height & $\mathrm{cm}$ & 1,0 & + \\
\hline 2. & Weight & $\mathrm{kg}$ & 0,5 & \\
\hline 3. & Body Mass Index & $\mathrm{kg} / \mathrm{m}^{2}$ & 0,01 & \\
\hline 4. & Stretch (horizontal) & $\mathrm{cm}$ & 1,0 & + \\
\hline 5. & Running 20 m sprinting & $\mathrm{S}$ & 0,01 & - \\
\hline 6. & Vertical rebound & $\mathrm{cm}$ & 1,0 & + \\
\hline 7. & Triple jump & $\mathrm{m}$ & 0,01 & + \\
\hline 8. & Running between stands & $\mathrm{s}$ & 0,01 & - \\
\hline 9. & Throwing of solid ball & $\mathrm{m}$ & 0,01 & + \\
\hline 10. & Occipital leg press (crunches) & number & 1,0 & + \\
\hline 11. & Running «Shuttle» $252 \mathrm{~m}$ & $\mathrm{~S}$ & 0,01 & - \\
\hline 12. & Leading the ball between stands & $\mathrm{S}$ & 0,01 & - \\
\hline 13. & Index of leading a ball & $\mathrm{S}$ & 0,01 & - \\
\hline 14. & Defense & $\mathrm{S}$ & 0,01 & - \\
\hline 15. & Eights with dribble & number & 1,0 & + \\
\hline 16. & High-speed shooting in motion - time & $\mathrm{s}$ & 0,01 & - \\
\hline 17. & High-speed shooting in motion - number & number & 1,0 & + \\
\hline & High-speed shooting in motion - coefficient & $\mathrm{S}$ & 0,01 & - \\
\hline & Rebound shooting with a passer & number & 1,0 & + \\
\hline 20. & Penalty shots - number of successful ones & number & 1,0 & + \\
\hline
\end{tabular}

The physical development and physical preparedness tests are standard and applied in the sports practice for many years. The tests for the technical skills are strictly specific for the different sports and for better illustration and perception of the information they should be described.

Description of the tests for technical skills used for basketball

Test 8 - Run between stands. From high start as initial position, the player is running along equilateral triangle with $10 \mathrm{~m}$ length of the side. Stands are posted at the three tops of the triangle and in the center. The route is shown in Figure 1. The direction of the start is by choice - to the right or to the left. The result is recorded with exactness of $0.01 \mathrm{~s}$.

Test 15 - Eights with a dribble. Initial position - basketball posture, feet are positioned more widely than shoulders, the ball is positioned at the right flank. Upon a signal, dribble is performed with the right hand on the right leg side, then crossed dribble follows by moving the ball from back forward through the legs, taking the ball with the left hand, dribble on the left leg side, crossed dribble from back forward between the legs to the right hand and so on. Each tap of the ball on the ground, performed without infringing the defined consecutiveness of the movements, is counted. The exercise is $30 \mathrm{~s}$ long. It is performed twice, and the better results are recorded.

Test 12 - Leading the ball between stands. The same exercise is performed as described for indicator 8 (running between stands) - see Figure 1 but the distance is overcome by leading the ball. The result is recorded with exactness of $0.01 \mathrm{~s}$. 


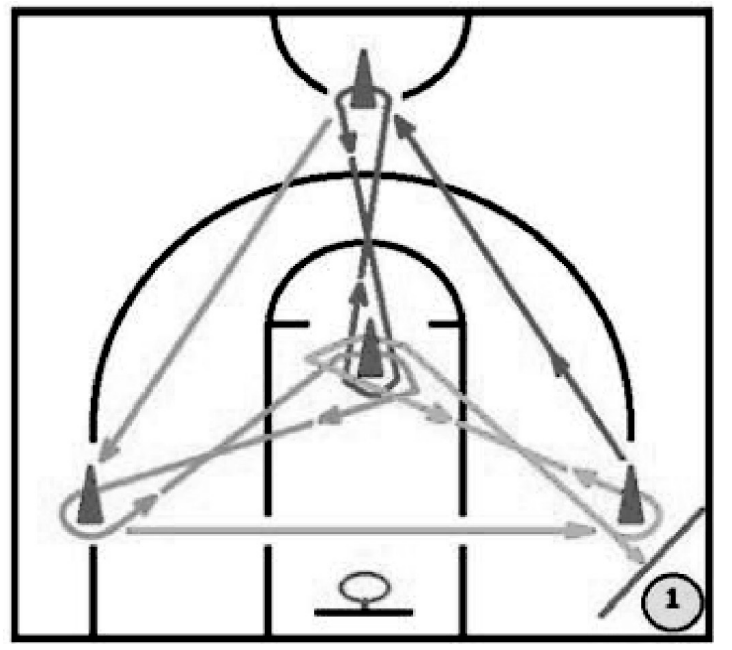

Figure 1. Diagram of positioning of the stands for the Tests 8 (Running between stands) and 12 Leading the ball (dribble) between stands

Test 13 - Leading the ball index. It presents the difference between the results of test 12 and test 8 , recorded in seconds with exactness of 0.01 .

Test 14 - Moving in defense. It is performed round a square with $5 \mathrm{~m}$ sides. Stands are posi- tioned at the angles (Figure 2). Running sprint on side 1-2, moving in defensive standing 2-3, running back on side 3-4 and then the distance is overcome in the same way in the reverse direction towards the initial position. The result is recorded with exactness up to $0.01 \mathrm{~s}$.

\section{(1)}

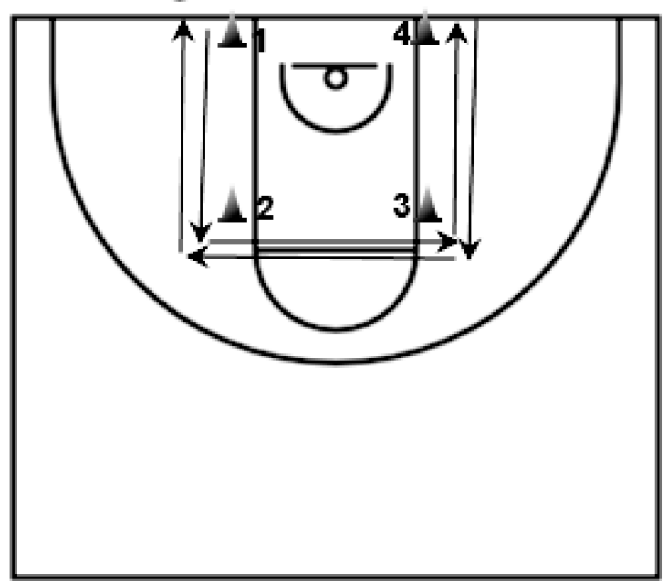

Figure 2. Diagram of positioning of the stands for Test 15 Moving in defense

Test 16 - Speed shot on the run. Initial position - high start at the base line (under the basket) holding the ball with hands. Roundabout is performed by leading the ball, then a shot to the basket while moving follows (after two steps) consecutively at each of the three stands, positioned at the $3 \mathrm{p}$ line (against the basket and under angle of $45^{\circ}$ from the left and from the right) - (Figure 3). Two tours are performed (6 shots total). During the first round the leading and shooting are performed with the dominant hand and during the second one - with the non-dominant one. The time of the performance is recorded with exactness of $0.01 \mathrm{~s}$, as well as the number of the successful shots into the basket (at correct coordination). 


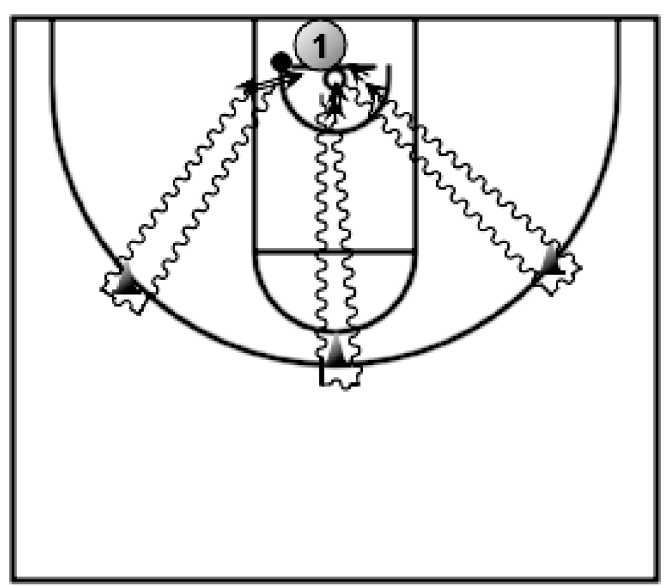

Figure 3. Diagram of positioning of the stands for Test 16 Speed-shot of the run

Test 17 - Speed shot while moving-number. The successful shots in the basket are recorded (correct coordination) while performing indicator No. 16.

Test 18 - Speed shot while moving. The coefficient of effectiveness for the speed shot while moving is calculated; the time of the performance is divided into the number of the successful shots in the basket. Exactness of up to $0,01 \mathrm{~s}$ is recorded.

Test 19 - Shot with feeder. Three series of 10 shots into the basket from 3 positions are performed:

$\checkmark$ perpendicular to the board;

$\checkmark$ under angle of $45^{\circ}$ to the board;

$\checkmark$ under angle of $0^{\circ}$ to the board.

The positions may be arranged in the left or right half of the playing ground (according to the executor's choice). After each series both players change positions. Shooting is performed at $5.00 \mathrm{~m}$ distance from the ring center projection on the ground. The total number of the successful shots into the basket for the three positions is recorded.

Test 20 - Free throws - number of successful ones. The number of the successful shots is recorded. The relative share of the successful shots in the basket against all free throws performed is calculated as a result of the test too.

\section{Data analysis}

For the realization of the purpose and tasks set for the study, the following methods of research were applied: survey study of the specific literature and sport-pedagogical testing.

The results from the study were subjected to mathematical-statistical processing with SPSS 23; depending on the tasks of the research the following statistical methods were applied:

- variation analysis - for defining the average values, normality of distribution and variety of the indicators under study;

- correlation analysis - for defining the degree of dependence between the indicators under study. Ordinary linear correlation was used according to the "everybody against everybody" method;

- factor analysis and Index method.

\section{RESULTS}

The main research task is related to the discovery of the factor structure of sports preparedness and the identification of the main factors that make up this structure. To solve the purpose and tasks of the research, the results of the conducted sports-pedagogical tests were subjected to processing with the help of correlation analysis. It reveals the relationships between the studied features and establishes their strength and direction in order to correctly apply factor anal- 
ysis. The absolute number of relationships and values of all correlation coefficients between the signs of physical development and the specific preparedness in basketball between the individual indicators are a lot and different in strength, which makes it difficult to analyze why their number is reduced based on the calculated correlation coefficient $(r)$ at a high degree of statistical reliability $\mathrm{Pt} \geq 99 \%$, at which critical $=300$.

In the analysis of the results, the qualitative assessment of the degree of dependence between each pair of indicators is in accordance with the norms of the sports statistics according to Gigova (2002).

The analysis of the correlation matrix showed that the total number of significant coefficients of ordinary linear Pearson correlation, between the observed 20 signs of physical development and specific preparedness, was 66 .

After deriving the correlation matrix with Pearson's coefficients for each pair of quantities of all variables, the results of the two tests of basketball players were processed by factor analysis. To solve the purpose and tasks of the study, two factor structures were derived for 15-16 year old athletes: one at the beginning of the study (at the beginning of the sports-competition year) and one at the end of the study (at the end of the sports-competition year).

The application of factor analysis allowed to derive the main components and on this basis to build the factor models of physical development and the specific performance of the studied population, as well as to reveal the features of each factor structure, depending on age and level of preparedness of the basketball players.

About 15-16-year-old basketball players, after extracting the 7 factors by the chosen method of Principal Component Analysis (PCA), we received the so-called initial factor solution in the Component Matrix with 7 components. The initial factor solution showed the 20 independent variables grouped into 7 com- ponents (factors). To understand how many factors would best describe the variability of the sample, we applied the rotation of the two factors with the varimax and Kaiser normalization methods and obtained the rotated solution, in which the components were again 7 , but the independent variables in them were different.

We can summarize that at the age of 15-16 years (at the beginning of the study) the factor structure of basketball players is composed of 7 main factors (Table 2), which explain a very high percentage of the initial variance of the studied phenomenon (82.61\%). Table 1 shows that the first factor F1 (component 1) clearly groups the variables associated with the different types of basketball shooting with weights of $.934, .913$, .776 and .741 , respectively. The variables related to anthropometric data with weights $.939, .936$, .823 and .451 , respectively, were grouped to the second factor F2. On the last variable - „Triple jump" the factor weight was of value 0.5 , it is considered by default that the weight threshold in this distinction is 0.5 , but the latter strongly depends on the sample size, in our case it was $n$ $=65$. When analyzing the table, it is important to know that if a variable participates with high weights in more than one factor, it is considered that the number of factors is not good and the corresponding factor model is rejected. If there is a variable whose participation is low in all factors, it is considered to have little influence in the data cloud and should be dropped from the factor model. No cloud-weakening variable was observed in our model.

The derived factors also show the place of the speed-power characteristics in the factor structure of 15-16-year-old basketball players at the beginning of the study. It is interesting that the indicators that carry information about them were present in the third, fourth, fifth and sixth factors. Only one indicator was in the second component, which had the lowest weight of all four variables - ,Triple jump“ (-.451). 
Table 2. Factor structure of physical development and physical capacity of 15-16-year-old basketball players at the beginning of the study

\begin{tabular}{|c|c|c|c|c|c|c|c|c|c|}
\hline Indicators & F I & F II & F III & F IV & $\mathbf{F V}$ & F VI & F VII & $\mathbf{h}$ & $1-h^{2}$ \\
\hline 1. High-speed shooting in motion - coefficient & .934 & .090 & .022 & .165 & .163 & .043 & .043 & .939 & .118 \\
\hline 2. High-speed shooting in motion - time & 913 & .072 & .005 & .096 & 147 & .001 & .066 & .874 & .236 \\
\hline 3. Penalty shots - number of successful ones & .776 & .083 & .335 & .068 & .093 & .188 & 072 & .774 & .401 \\
\hline 4. High-speed shooting in motion - number & .741 & .137 & .198 & .306 & 255 & .142 & .035 & .787 & .381 \\
\hline 5. Stretch (horizontal) & .033 & 939 & .022 & .080 & .069 & .084 & .077 & .908 & .176 \\
\hline 6. Height & .045 & .936 & .081 & .026 & .089 & .071 & 030 & .900 & .190 \\
\hline 7. Weight & .065 & .823 & .040 & .001 & .092 & .517 & 027 & .959 & .08 \\
\hline 8. Triple jump & .225 & .451 & .402 & .213 & .364 & .163 & 090 & .628 & .606 \\
\hline 9. Occipital leg press (crunches) & .026 & .028 & .758 & .155 & .063 & .233 & .139 & .678 & .54 \\
\hline 10. Runn & .147 & .139 & .739 & .104 & .302 & .093 & .122 & .712 & .493 \\
\hline 11. $\mathrm{Rl}$ & .013 & .01 & .634 & .375 & .359 & .281 & .354 & .876 & .233 \\
\hline 12. $\mathrm{T}$ & .367 & .356 & .620 & .010 & .029 & .388 & .067 & .801 & .358 \\
\hline $\mathrm{h}$ a passer & .428 & .375 & .557 & .308 & .038 & .076 & .078 & .742 & .449 \\
\hline 14. Running $\mathrm{b}$ & .273 & .08 & 198 & .862 & .117 & .075 & .008 & .882 & .222 \\
\hline e ball betw & .221 & .116 & .217 & .703 & .133 & .032 & .595 & .976 & .047 \\
\hline 16. Defense & .153 & .075 & .076 & .197 & .852 & .016 & .045 & .801 & .358 \\
\hline 17. Eights with dribble & .387 & .371 & .216 & .075 & .641 & .049 & .187 & .788 & .379 \\
\hline 18. BMI & .051 & .342 & .047 & .035 & .068 & .817 & .019 & .796 & .366 \\
\hline 19. $\mathrm{Vs}-a$ & .134 & .252 & .152 & .473 & .386 & .538 & .02 & .767 & .412 \\
\hline 20. Index of leading a ball & .009 & .084 & .097 & .036 & .064 & .043 & .954 & .934 & .128 \\
\hline$\sum \mathrm{a}^{2}=82.61 \%$ & $\begin{array}{l}0 \\
0 \\
0 \\
0 \\
0\end{array}$ & $\begin{array}{l}\stackrel{0}{\circ} \\
\stackrel{\Delta}{a} \\
\stackrel{a}{a}\end{array}$ & $\begin{array}{l}\dot{\partial} \\
\hat{\sigma}\end{array}$ & $\begin{array}{l}e^{\circ} \\
\stackrel{0}{a} \\
\stackrel{0}{0}\end{array}$ & $\frac{\stackrel{0}{+}}{b}$ & $\begin{array}{l}\dot{0} \\
\dot{0} \\
\dot{0} \\
\dot{0}\end{array}$ & $\stackrel{0}{\circ}$ & & \\
\hline
\end{tabular}

In addition to the factor weights, the table plained $\left(h^{2}\right)$ as well as the unexplained $\left(1-h^{2}\right)$ also presents data on the magnitude of the ex- of the initial variance of each studied feature.

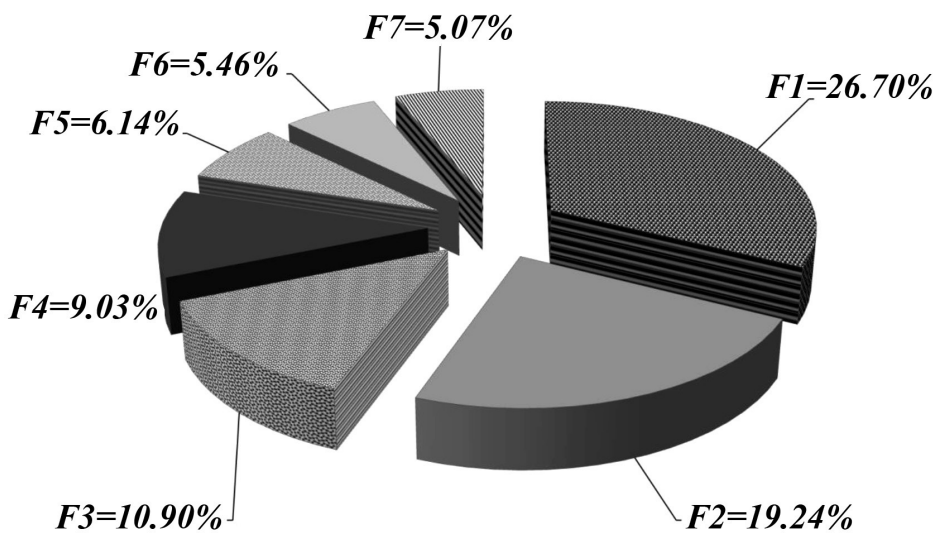

Figure 4. Relative share of the initial variance explained by each factor in 15-16 year old basketball players at the beginning of the study

The relative shares of the initial variance explained by each factor are illustrated in Figure 4. The analysis of Figure 4, shows that the first derived factor explains $26.70 \%$, the second explains $19.24 \%$, the next two have a lower contribution to the total physical development and the specific working capacity of the basket- ball players (respectively $10.90 \%$ and $9.08 \%$ ), and the last three are additional and the variance explained by them is less than $10 \%$.

The first factor in the factor structure of physical development and the specific performance of 15-16-year-old basketball players at the beginning of the study is determined by 
four main indicators (Figure 5), which explain the highest percentage of the initial variance of the studied phenomenon. (26.70\%). This factor reveals the high importance of the skills and speed of scoring a point in shooting on the move, as well as the scoring of penalty shots for the general preparedness of the basketball play- ers from the studied population. This allows it to be identified as a technical-tactical factor. The second factor (19.24\%) can be defined as morphological. It reveals the place in the factor structure of the height-weight indicators, which are a prerequisite for higher achievements in the performance of a triple jump (Figure 5).

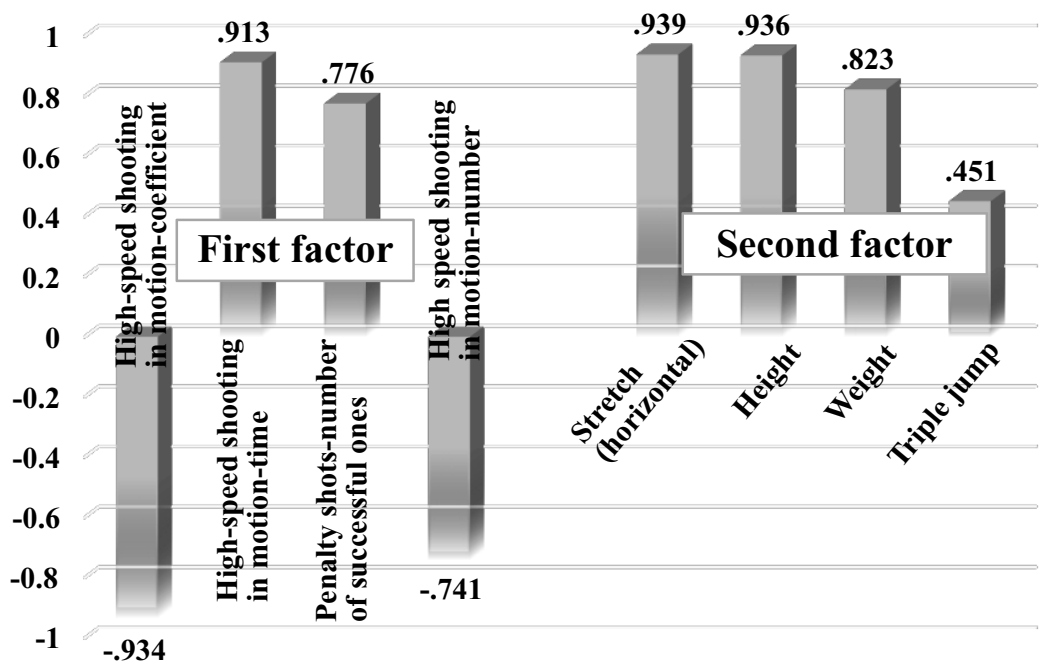

Figure 5. Factor structure of 15-16 year old basketball players at the beginning of the study - I and II factors

The third factor $(10.90 \%)$ determines the place in the factor structure of 15-16-year-old basketball players of speed and strength abilities and their positive influence on the ability to score a shot when shooting from a position with a passer (Figure 6).

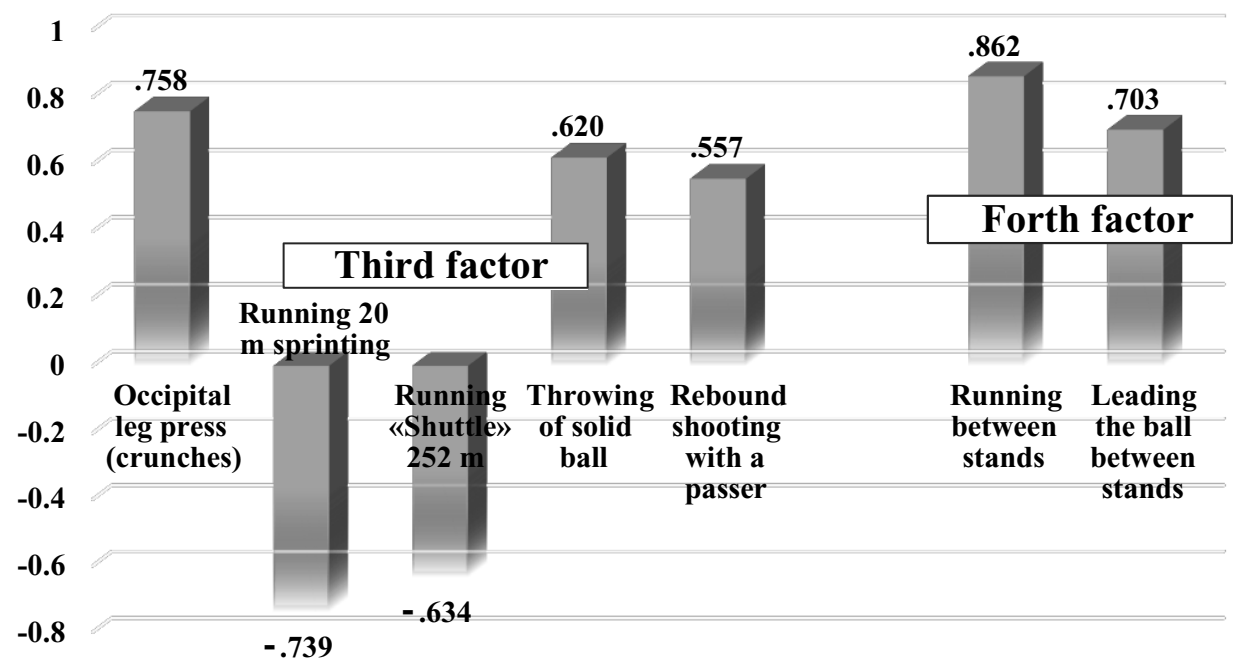

Figure 6. Factor structure of 15-16 year old basketball players at the beginning of the study III and IV factors 
The fifth factor $(6.15 \%)$ determines the ability to handle the ball on the spot and the speed of movement in defense (Table 2).

The sixth factor $(5.46 \%)$ determines the influence of body mass index on the explosive force of the lower extremities during vertical muscular effort (Table 2).

The seventh factor is the last factor in the factor structure and makes up 5.07\%. It includes only one indicator that determines the ability to lead the ball at high speed. This means that this feature does not give an advantage to the studied basketball players (Table 2).

After a year of practice and competition, the factor structure of physical development and the specific working c apacity of 15-16 year old basketball players underwent significant changes. Table 3 shows that at the end of the study the derived factor structure explained a lower percentage of the initial dis- persion (76.64\%) of the studied phenomenon, compared to the factor structure after the first study.

Table 3 presents the derived factors, which show that after one year, the factor structure of basketball players was already made up of 5 main factors. The table shows that in the first factor F1 (component 1) six variables are clearly grouped, mainly related to speed-power capabilities and factor weights, respectively $.864, .828, .703, .692$ and -.500 .

Four variables are grouped to the second factor F2, and after the first study, they are related to the anthropometric data with factor weights $.909, .881, .843$ and .741 , respectively.

In addition to the factor weights, the table also presents data on the magnitude of the explained $\left(h^{2}\right)$ as well as the unexplained $\left(1-h^{2}\right)$ of the initial variance of each studied feature.

Table 3. Factor structure of the physical development and physical capacity of 15-16 year old basketball players at the end of the study

\begin{tabular}{|c|c|c|c|c|c|c|c|c|}
\hline № & Indicators & F I & F II & F III & F IV & $\mathbf{F V}$ & h & $1-h^{2}$ \\
\hline 1. & Running between stands & .889 & 200 & -.080 & .016 & -.104 & .848 & .281 \\
\hline 2. & Leading the ball between stands & .864 & .135 & .114 & -.005 & .354 & 903 & .185 \\
\hline & Defense & .828 & .000 & .228 & .039 & -.268 & .811 & .342 \\
\hline & High-speed shooting in motion - number & .703 & -.091 & 577 & -.073 & .123 & .856 & .267 \\
\hline & Running «Shuttle» $252 \mathrm{~m}$ & 692 & -.057 & -.017 & -.053 & .088 & 494 & .756 \\
\hline & Occipital leg press (crunches) & -.500 & .402 & .219 & .054 & 179 & .494 & .756 \\
\hline & Weight & 093 & .909 & -.089 & -.188 & -.162 & .905 & .181 \\
\hline & Stretch (horizontal) & 194 & .881 & -.133 & -.041 & -.088 & .840 & .294 \\
\hline & Height & 108 & .843 & -.388 & -.027 & 144 & 894 & 201 \\
\hline 10. & Throwing of solid ball & -.423 & .741 & .109 & .116 & -.211 & 797 & .365 \\
\hline 11. & High-speed shooting in motion - coefficient & 162 & -.170 & .912 & .090 & 126 & 911 & .170 \\
\hline 12. & High-speed shooting in motion - time & .042 & .173 & -.875 & -.111 & -.116 & .822 & .324 \\
\hline 3. & BMI & -.011 & .220 & .496 & -.284 & -.487 & 613 & .624 \\
\hline 14. & Rebound shooting with a passer & .030 & -.031 & .230 & .847 & .014 & .773 & .402 \\
\hline 15. & Penalty shots - number of successful ones & 227 & -.374 & -.117 & 734 & 127 & .760 & .422 \\
\hline 16. & Vertical jump & -.306 & 284 & .033 & .659 & -.105 & .621 & .614 \\
\hline 17. & Eights with dribble & -.480 & -.378 & -.282 & .491 & .057 & 696 & .516 \\
\hline 18. & Index of leading a ball & .110 & -.079 & .330 & -.034 & .791 & .754 & .431 \\
\hline 7. & Triple jump & -.019 & .518 & -.138 & -.058 & -.655 & .719 & .483 \\
\hline 5. & Running $20 \mathrm{~m}$ sprinting & -.384 & .364 & -.411 & -.068 & .603 & .817 & .333 \\
\hline \multicolumn{2}{|r|}{$\sum \mathrm{a}^{2}=76.64 \%$} & $\begin{array}{l}\dot{ }^{\circ} \\
\vec{\sigma} \\
\stackrel{+}{\sim}\end{array}$ & $\begin{array}{l}\overbrace{}^{\circ} \\
\stackrel{n}{\sim} \\
\end{array}$ & 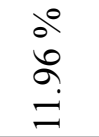 & $\begin{array}{l}\stackrel{0}{a} \\
\tilde{n} \\
a\end{array}$ & $\begin{array}{l}\stackrel{0}{\circ} \\
\text { } \\
\text { aे }\end{array}$ & & \\
\hline
\end{tabular}


Compared to the factor structure of the first $(24.61 \%)$ and the second component 15-16-year-old basketball players at the be- had the highest percentage $(21.25 \%)$ and exginning of the study and at the end of the study, plained almost $46 \%$ of the sample (Figure 7).

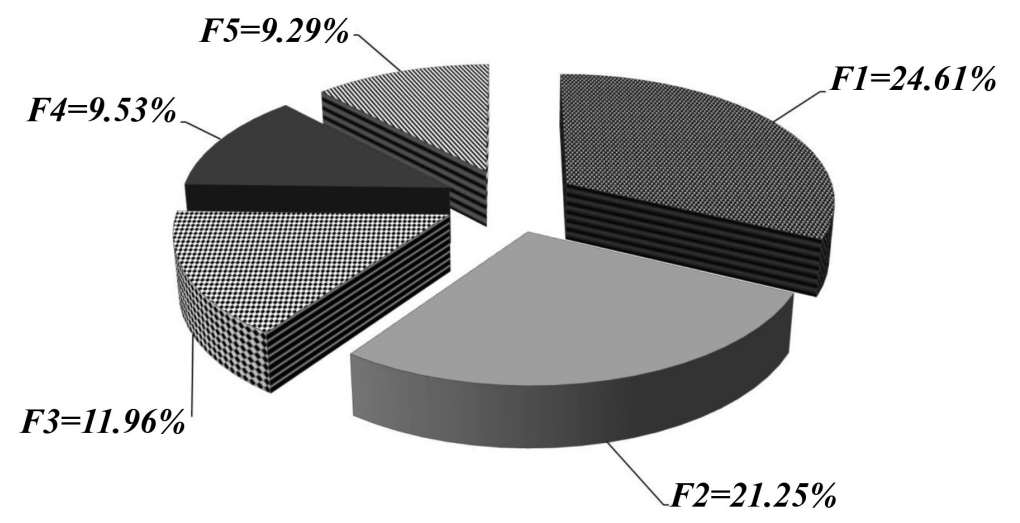

Figure 7. Relative share of the initial variance explained by each factor in 15-16-year-old basketball players at the end of the study

In the first component presented in Figure 8 , it is seen that there was an increase in the contribution of the speed of movement on the field without the ball and with the ball, the performance of the protective posture, the speed endurance and the strength of the abdominal muscles. At the beginning of the study, these variables were located in the third and fourth factor components.
The second component can be considered as morphological, because it includes all anthropometric indicators, as at the beginning of the study, but here we already have an indicator related to the explosive power of the upper limbs, which shows that height and weight are a prerequisite for higher achievements when throwing a solid ball.

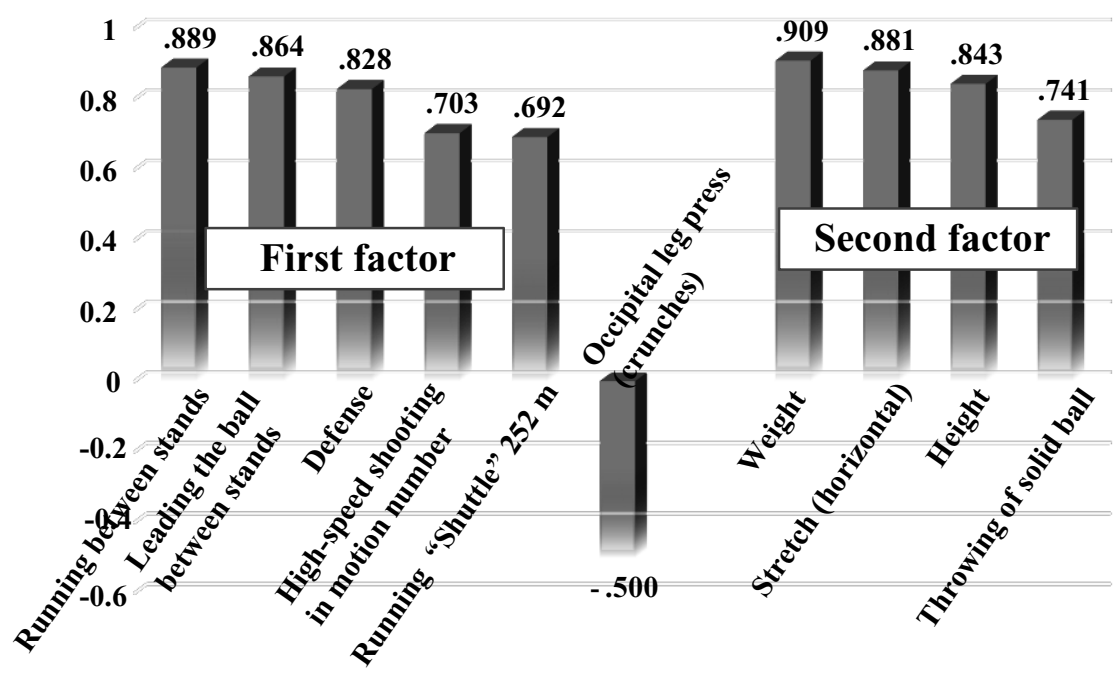

Figure 8. Factor structure of 15-16 year old basketball players at the end of the study - I and II factors 


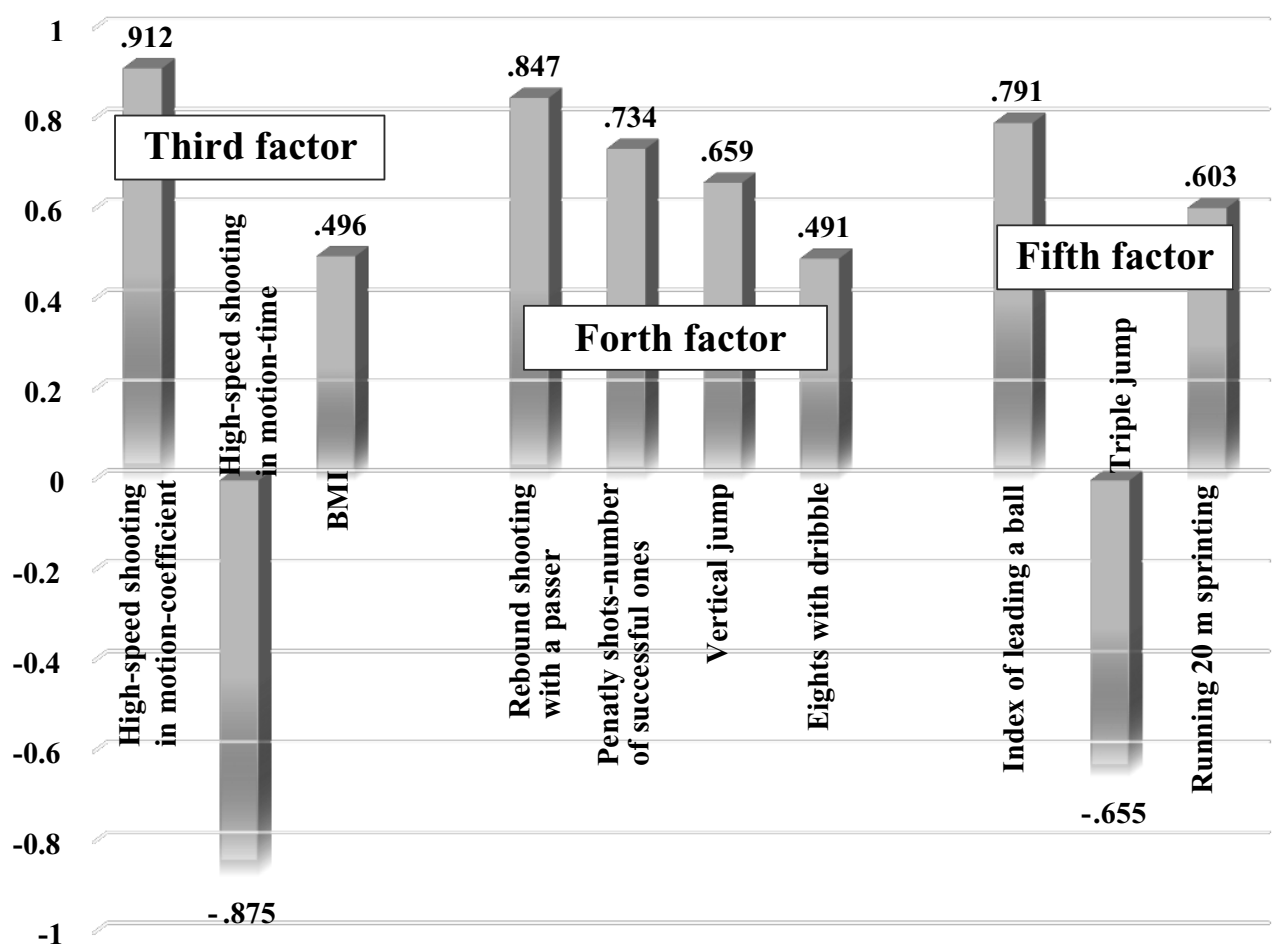

Figure 9. Factor structure of 15-16 year old basketball players at the end of the study - III, IV and V factors

The third component of the general physical and technical-tactical preparedness at the end of the research presented in Figure 9 included the ability to quickly score points and the body mass index.

Although the last two components had the lowest percentage of the explained dispersion $(\mathrm{F} 4=9.53 \%$ and $\mathrm{F} 5=9.29 \%)$, the fourth component (Figure 9) determined the second to last place in the factor structure of the accuracy of the shot from the penalty line, the shot from position, the explosive power of the lower limbs in vertical efforts, as well as the ability of basketball players to keep the ball in place. They show that at the end of the study, the effectiveness of shooting from the penalty line and shooting from a position had lost its significance as one of the most important signs of physical development and specific performance.

The fifth component (Figure 9) determines the place in the factor structure of the special speed of movement, of guiding the ball and the explosive force of the lower limbs in horizontal muscular efforts.

\section{DISCUSSION}

The factor analysis made at the beginning and at the end of the study showed that in this age group within a sports-competitive year there is dynamics in terms of physical development of basketball players in this age group. At the beginning of the study, athletes were in a period when strength was increasing and this should be used rationally by coaches. At the end of the study, some of the basketball players were at the end of their 16 years, and this is the age when the topography of muscle strength is formed. In adults, strength increases, which shows that our methodology for developing speed and strength in 15-16-year-old basketball players is suitable and can be applied in the annual training cycle with young players. A similar study conducted by Tsarov and Tsarova with 125 basketball players (15- 
16-year- old), who, however, were included in the national team of Bulgaria in the period 2009-2016 found eight components. The socalled morphological factor, revealing the high significance mainly of the linear dimensions of the body, was the most important for the general preparedness of 15-16-year-old basketball players. Indicators related to the physical preparedness of athletes identified the fourth last factor as the so-called ,basketball athletics“.

According to Tsarova (2013), the results of factor analysis can serve as a particular criteria for optimization. This means that the traits reported in each athlete with a low level of development (low sigma scores $T$ ) should be rearranged depending on the significance of each trait, reported according to the place of this trait in the integral factor structure of sports preparedness.

\section{CONCLUSIONS}

The derived correlation-factor structure of the studied indicators for the physical development, physical and technical-tactical preparedness of adolescent basketball players, before and after the tested training program, led to some shifts in the significance of the indicators. At the beginning of the study among 15-16-year-old athletes the greatest contribution to the general physical and specific training had a high efficiency in high-speed shooting in motion, in the execution of penalty shots, and height - weight indicators were a prerequisite for higher performance in a triple jump, while at the end of the study the speed-strength abilities were of crucial importance and again the height-weight indicators were a prerequisite for higher achievements, but when throwing a solid ball - forward.

\section{ACKNOWLEDGMENT}

The authors are grateful to the basketball players from BC „Beroe“, BC „Tundzha“, BC
„CSKA“, BC „Academic-Bultex“ and their coaches. Without their participation, this study would not have been possible.

\section{REFERENSES}

Borukova, M. (2018). Control na sportnata podgotovaka pri 13-14 godishni basketbolistki. Sofia, Bolid ins. // Борукова, М. (2018). Контрол на спортната подготовка при 1314 годишни баскетболистки. София, Болидинс. ISBN 978-954-394-242-8

Gigova, V. (2002). Statisticheska obrabotka I analiz na Danni, Sofia, NSA-IPB. // Гигова, В. (2002). Статистическа обработка и анализ на данни, София, НСА - ИПБ

Matveev. L.P. (1977). Osnovы sportivnoy trenirovki: uch. pos. Fizkulytura i sport. Moskva. // Матвеев, Л.П. (1977). Основы спортивной тренировки : уч. пос. Физкультура и спорт. Москва.

Tsarov, Kr. (2001). Faktori na sastezatelnata efektivnost na elitni otbori po basketbol. Avtoref. na dis. Trud. NSA. Sofia. // Църов, Кр. (2001). Фактори на състезателната ефективност на елитни отбори по баскетбол. Автореф. на дис. Труд. НСА. София

Tsarov, Kr., Djordjevich, B. (1997). Basketbol - trenyorsko rakovodstvo. Sofia: NSAIPB. // Църов, Кр., Джорджевич, Б. (1997). Баскетбол - треньорско ръководство. София: НСА-ИПБ.

Tsarova, R., Tsarov, K. (2007). Testova bateriya za nachalen podbor $v$ basketbola, BFB, Sofiya. // Църова, Р., Цьров, К. (2007). Тестова батерия за начален подбор в баскетбола, БФБ, София.

Tzarov, K. (2008). Podborat v basketbola. Sofia \& NSA Pres. // Църов, Кр. (2008). Подборът в баскетбола. София: НСА Прес. Tzarova, R. (2013). Problemi na kontrola $v$ basketbola, Sofia, Bolid ins. // Цьрова, Р. (2013). Проблеми на контрола в баскетбола. София. Болид инс. 
Tzarova, R., Borukova, M. (2012). Izsledvane varhu nivoto na podgotvenost na uchenitsite, kandidatstvashti v sportnite uchilishta s profil basketbol, Sport \& Nauka, S., 2011/2, pp. 89-97 // Tzarova, R., Borukova, M. (2012). Изследване върху нивото на подготвеност на учениците, кандидатстващи в спортните училища с профил баскетбол, Спорт и наука, С., 2011/2, стр. 89-97

Yahontov, E. (2006). Individualynaya podgotovka basketbolistov. SPb., pp. 112 // Яхонтов, Е. (2006). Индивидуальная подготовка баскетболистов. СПб., 112 с.

Zhelyazkov, Ts. (1978). Metodologi- chni osnovi na upravlenieto i optimiziraneto na sportnata podgotovka pri visokokvalifitsirani sportisti, Dis. trud - dpn, Sofiya: VIF. // Желязков, Ц. (1978). Методологични основи на управлението и оптимизирането на спортната подготовка при висококвалифицирани спортисти, Дис. труд - дпн, София: ВИФ.

Zhelyazkov, Ts., Dasheva, D. (2017). Osnovi na sportnata trenirovka. Bolid Ins. ISBN 978-954-394-222-0. Sofiya. // Желязков, Ц., Дашева, Д. (2017). Основи на спортната тренировка. Болид Инс. ISBN 978-954-394222-0. София.

Corresponding author:

Mariana Borukova

Department „Basketball, Volleyball, Handball” National Sports Academy „Vassil Levski” 21, Acad. Stefan Mladenov Str.

Sofia 1700, Bulgaria E-mail: marianaborukova@gmail.com 